\title{
Py-GC/MS study of lignin pyrolysis and effect of catalysts on product distribution
}

\author{
Si Zhan ${ }^{1,2,3}$, Wang Chenguang ${ }^{2 *}$, Bi Kang ${ }^{2,4}$, Zhang Xinghua ${ }^{2}$, Yu Chiling ${ }^{5}$, \\ Dong Renjie ${ }^{1,3,6^{*}}$, Ma Longlong ${ }^{2}$, Pang Changle ${ }^{7}$
}

(1. Bioenergy and Environment Science \& Technology Laboratory, College of Engineering, China Agricultural University, Beijing 100083, China; 2. Key Laboratory of Renewable Energy, Guangzhou Institute of Energy Conversion, Chinese Academy of Sciences, Guangzhou 510640, China; 3. Key Laboratory of Clean Production and Utilization of Renewable Energy, Ministry of Agriculture, Beijing 100083, China; 4. School of Chemical Engineering and Energy, Zhengzhou University, Zhengzhou 450001, China; 5. State Key Laboratory of Organic Geochemistry, Guangzhou Institute of Geochemistry, Chinese Academy of Sciences, Guangzhou 510640, China; 6. National Center for International Research of BioEnergy Science and Technology, Ministry of Science and Technology, Beijing 100083, China;

7. Department of Vehicle Engineering, College of Engineering, China Agricultural University, Beijing 100083, China)

\begin{abstract}
Fast pyrolysis is one of the most promising methods to convert lignin into fuels and chemicals. In the present study, pyrolysis-gas chromatography/mass spectrometry (Py-GC/MS) was used to evaluate vapor phase product distribution of lignin fast pyrolysis. During the non-catalytic pyrolysis process, lignin was pyrolyzed at $400^{\circ} \mathrm{C}, 500^{\circ} \mathrm{C}$ and $600^{\circ} \mathrm{C}$ respectively, finding that the highest yield of aromatic hydrocarbons was obtained at $600^{\circ} \mathrm{C}$. Catalytic pyrolysis experiments were also conducted to investigate the effects of catalyst pore structure and acidity on the product distributions. Five different catalysts (HZSM-5, MCM-41, $\mathrm{TiO}_{2}, \mathrm{ZrO}_{2}$ and $\mathrm{Mg}(\mathrm{Al}) \mathrm{O}$ ) were applied to lignin catalytic pyrolysis, and the catalytic performance was estimated by analyzing the pyrolytic products. The catalysts were characterized by using X-ray diffraction (XRD), BET, and $\mathrm{NH}_{3}\left(\mathrm{CO}_{2}\right)$ temperature programmed desorption. Based on these characterizations, discussion was carried out to explain the formation of the produc distributions. Among the five catalysts, HZSM-5 exhibited the best performance on the formation of aromatic hydrocarbons.
\end{abstract}

Keywords: lignin, Py-GC/MS, fast pyrolysis, catalytic upgrading, pore structure, acid-base property

DOI: $10.25165 /$ j.ijabe.20171005.2852

Citation: Si Z, Wang C G, Bi K, Zhang X H, Yu C L, Dong R J, et al. Py-GC/MS study of lignin pyrolysis and effect of catalysts on product distribution. Int J Agric \& Biol Eng, 2017; 10(5): 214-225.

\section{Introduction}

Due to the depletion of fossil resources and concerns over carbon emission, lignocellulosic biomass has

Received date: 2016-09-13 Accepted date: 2017-06-14

Biographies: Si Zhan, PhD candidate, major in biomass catalytic conversion, Email: sizhan43@126.com; Bi Kang, Master, major in biomass catalytic conversion, Email: bikang@ms.giec.ac.cn; Zhang Xinghua, Associate professor, major in biomass catalytic conversion, Email: zhangxh@ms.giec.ac.cn; Yu Chiling, Senior Engineer, major in analytical test, Email: yuchiling@gig.ac.cn; Ma Longlong, Professor, major in biomass utilization and conversion, Email: mall@ms.giec.ac.cn. Pang Changle, Professor, major in vehicle engineering, Email: pangcl@cau.edu.cn. emerged as a promising renewable feedstock for the production of fuels and chemicals. Pathways for biomass conversions can be categorized as biochemical or thermochemical processes. Fast pyrolysis of biomass and its three major components (i.e. cellulose,

\footnotetext{
*Corresponding author: Wang Chenguang, Professor, major in biomass catalytic conversion, Guangzhou Institute of Energy Conversion, Chinese Academy of Sciences, No.2 Wushan Nengyuanlu, Tianhe District, Guangzhou 510640, China. Tel/Fax: +86-20-37029721, Email: wangcg@ms.giec.ac.cn.

Dong Renjie, Professor, major in biomass engineering, China Agricultural University, No. 17 Qinghua Donglu, Haidian District, Beijing 100083, China. Tel/Fax: +86-10-62737885, Email: rjdong@cau.edu.cn.
} 
hemicelluloses and lignin) is a relatively simple thermochemical process which is usually conducted at a temperature of $400^{\circ} \mathrm{C}-600^{\circ} \mathrm{C}$ in the absence of oxygen ${ }^{[1]}$, and has the advantages of high conversion efficiency and environmentally friendly ${ }^{[2]}$. One of the primary advantages of fast pyrolysis is that solid biomass can be directly converted to liquid fuels, i.e. pyrolysis oil. However, high oxygen content $(20 \%-40 \%)$ of pyrolysis oil leads to undesirable properties such as low energy density, high viscosity and corrosion, thermal and chemical instability. Thus, catalytic upgrading was used to improve the qualities of pyrolysis oil. Catalytic pyrolysis was proved to be an effective way to improve the bio-oil quality. Aho et al. ${ }^{[3]}$ carried out catalytic pyrolysis of pine wood with $\mathrm{H} \beta, \mathrm{HY}, \mathrm{HZSM}-5$ and Mordenite, finding that acids and alcohols were decreased in the presence of HZSM-5. Zhang et al. ${ }^{[4]}$ studied the effect of HZSM-5 on fast pyrolysis of corncob in a fluidized bed, proposing that the existence of catalyst could decrease $25 \%$ oxygen content of pyrolysis oil, while increase the yields of gas, water and coke. On account of the complexities of pyrolysis process and productions, some researchers turned to investigate the catalytic pyrolysis of individual component of lignocellulosic biomass to further understand the pyrolysis mechanisms. Carlson et al. ${ }^{[5]}$ tested several catalysts including ZSM-5, silicalite, $\beta$, Y-zeolite and silica-alumina on the pyrolysis of cellulose and obtained the highest yield of aromatics in the presence of ZSM-5. Karanjkar et al. ${ }^{[6]}$ obtained a similar aromatic yield of $39.5 \%$ C from catalytic pyrolysis of cellulose using ZSM-5 as catalyst. Zhu et al. ${ }^{[7]}$ investigated the effect of HZSM-5 and M/HZSM-5 (M = Fe, Zn) on xylan pyrolysis, revealing that catalytic pyrolysis reduced oxygenates yield and increased hydrocarbons yield. Kim et al. ${ }^{[8]}$ presented that mesoporous $Y$ zeolite with larger quantity and stronger acidity could also reduce the oxygenates content and increase the aromatics to a larger extent from xylan pyrolysis. Guo et al. ${ }^{[9]}$ found that USY catalyst performed the best effect on deoxygenation than HZSM-5 and $\mathrm{H} \beta$ in xylan pyrolysis.

A representative lignin structure showing three primary units is illustrated in Figure $1^{[10]}$. The difference with cellulose and hemicellulose, lignin is a cross-linked amorphous biopolymer of three primary units including guaiacol (G), syringyl (S) and p-hydroxyphenol $(\mathrm{H})$ units which are bonded with $\mathrm{C}-\mathrm{O}-\mathrm{C}$ and C-C bonds ${ }^{[11]}$. Additionally, the content of each unit is varied with plant types. For example, conifer wood (softwood) contains 90\%-95\% G unit, $0-1 \% \mathrm{~S}$ unit and $0.5 \%-3.4 \% \mathrm{H}$ unit $^{[12]}$. The aromatic rings existed in the primary units are conducive to the immediate conversion of lignin to aromatic products ${ }^{[13]}$. However, the wide distribution of lignin pyrolysis productions caused by the complex structure ${ }^{[14,15]}$ results in receiving relatively less attention compared to cellulose and hemicellulose. Hence, the understanding of pyrolysis process and the effect of catalyst is essential Thring et al. ${ }^{[16]}$ investigated the effect of HZSM-5 in the catalytic pyrolysis of lignin in a fixed bed reactor and obtained the highest toluene yield (44 wt.\%) at $650^{\circ} \mathrm{C}$. The deactivation of zeolite catalyst during lignin pyrolysis was likely caused by simple phenols produced from the deconstruction of the lignin polymer ${ }^{[17]}$. The role of shape selectivity in lignin pyrolysis was studied by $\mathrm{Yu}$ et al. ${ }^{[18]}$, suggesting that ZSM-5 produced the highest aromatic yield, while $\beta$ zeolite was suited to convert bulky oxygenates. Adhikari et al. ${ }^{[19]}$ used four zeolite catalysts with different $\mathrm{SiO}_{2} / \mathrm{Al}_{2} \mathrm{O}_{3}$ ratios to catalyze torrefied lignin pyrolysis, and as high as 35 wt.\% carbon yield of aromatic hydrocarbons was obtained in the presence of the zeolite with $\mathrm{SiO}_{2} / \mathrm{Al}_{2} \mathrm{O}_{3}=30$. Extensive researches focused on the zeolite catalysts and the effect of acidic sites on the pyrolysis of lignin. In comparison, less investigation focused on the catalytic pyrolysis over metal oxides with acidic/base property. In the present study, five catalysts with different properties including HZSM-5, MCM-41, $\mathrm{TiO}_{2}, \mathrm{ZrO}_{2}$ and $\mathrm{Mg}(\mathrm{Al}) \mathrm{O}$ were selected to investigate the influences of pore size, acidic and base properties on lignin pyrolysis. The experiments were conducted by using a Py-GC/MS system and the yield and product distribution were systematically studied to reveal the effects of different catalysts. 


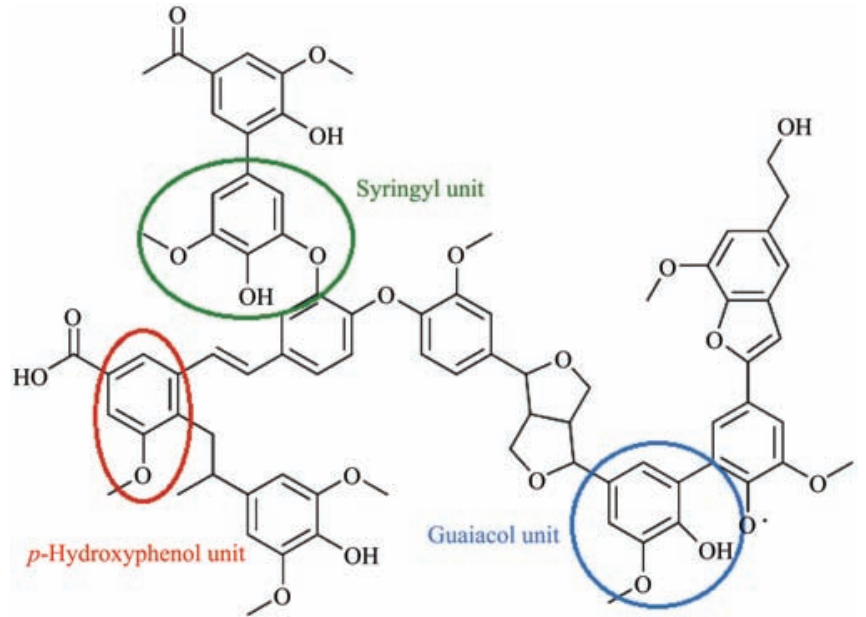

Figure 1 Representative structure models of lignin. Adapted from Kloekhorst et al. ${ }^{[10]}$

\section{Experimental materials and layout}

\subsection{Materials}

Lignin used in this study was a Kraft lignin from softwood obtained from Mead Westvaco Co. (USA). Commercial zeolites HZSM-5 (Si/Al=38) and MCM-41 were purchased from Nankai University Catalyst Co., Ltd; $\mathrm{ZrO}_{2}$ and $\mathrm{TiO}_{2}$ were purchased from Aladdin; The $\mathrm{MgAlO}(\mathrm{Mg} / \mathrm{Al}$ molar ratio $=2: 1)$ catalyst was prepared in the following manner: solution A was prepared by dissolving $10.0 \mathrm{~g} \quad \mathrm{Mg}\left(\mathrm{NO}_{3}\right)_{2} \cdot 6 \mathrm{H}_{2} \mathrm{O}$ and $7.76 \mathrm{~g}$ $\mathrm{Al}\left(\mathrm{NO}_{3}\right)_{3} \cdot 9 \mathrm{H}_{2} \mathrm{O}$ in $50 \mathrm{~mL}$ of deionized water; solution $\mathrm{B}$ was prepared by dissolving $3.82 \mathrm{~g} \mathrm{NaOH}$ and $4.38 \mathrm{~g}$ $\mathrm{Na}_{2} \mathrm{CO}_{3}$ in $50 \mathrm{~mL}$ of deionized water. Solutions A and B were simultaneously added dropwise to $50 \mathrm{~mL}$ of deionized water with constant stirring at $100^{\circ} \mathrm{C}$ for $12 \mathrm{~h}$. After that, the slurry was filtered, completely rinsed with distilled water and dried at $100^{\circ} \mathrm{C}$ for $8 \mathrm{~h}$. Finally, the dried product was calcined at $550^{\circ} \mathrm{C}$ in air for $5 \mathrm{~h}$ with a heating rate of $5^{\circ} \mathrm{C} / \mathrm{min}$. $\mathrm{Mg}\left(\mathrm{NO}_{3}\right)_{2} \cdot 6 \mathrm{H}_{2} \mathrm{O}$, $\mathrm{Al}\left(\mathrm{NO}_{3}\right)_{3} \cdot 9 \mathrm{H}_{2} \mathrm{O}, \mathrm{NaOH}$ and $\mathrm{Na}_{2} \mathrm{CO}_{3}$ used here were analytical grade and obtained from Aladdin Reagent Co., Ltd (Shanghai, China). Lignin and catalysts were all dried at $80^{\circ} \mathrm{C}$ for $12 \mathrm{~h}$ before use.

\subsection{Characterization}

FT-IR spectra were obtained on a Nicolet iS50 FT-IR spectrophotometer (Thermo Scientific, USA). A mercury cadmium telluride (MCT) detector was used and the spectrum was recorded in the range of $4000-500 \mathrm{~cm}^{-1}$. Elemental analysis were performed by a vario EL cube elemental analyzer (Elementary, Germany) which reported the composition of lignin in weight percentage of carbon, hydrogen, nitrogen and sulfur. The content of oxygen was calculated by difference.

The crystallographic properties of the catalysts were characterized on an X-ray diffractometer (X'pert PRO, Panalytical, Netherlands) with a $\mathrm{CuKa}(\lambda=0.154 \mathrm{~nm})$ radiation source operated at $40 \mathrm{kV}$ and $100 \mathrm{~mA}$. The $2 \theta$ ranged from $5^{\circ}$ to $80^{\circ}$ with $0.02^{\circ}$ step size.

The textural properties of catalysts were determined by $\mathrm{N}_{2}$ (or Ar for HZSM-5) isothermal adsorption using a QUADRASORB SI analyzer equipped with QuadraWin software system. Prior to analysis, all samples were degassed at $300^{\circ} \mathrm{C}$ for $8 \mathrm{~h}$. The surface area was analyzed by the Brunauer-Emmett-Teller (BET) method and the pore size distribution was calculated by Density Functional Theory (DFT) method.

The density and strength of acid sites of catalysts were determined by $\mathrm{NH}_{3}$ temperature-programmed desorption $\left(\mathrm{NH}_{3}-\mathrm{TPD}\right)$. The sample $(200 \mathrm{mg})$ was firstly pre-treated at $400^{\circ} \mathrm{C}$ for $60 \mathrm{~min}$ in Helium, then cooled to $30^{\circ} \mathrm{C}$ and exposed to a $10 \% \mathrm{NH}_{3} / \mathrm{He}$ stream for $60 \mathrm{~min}$. The desorption of $\mathrm{NH}_{3}$ was carried out by flushing with $\mathrm{He}$ by increasing the temperature to $850^{\circ} \mathrm{C}$ at the heating rate of $10^{\circ} \mathrm{C} / \mathrm{min}$.

The basic characteristics of the $\mathrm{Mg}(\mathrm{Al}) \mathrm{O}$ catalyst was studied with $\mathrm{CO}_{2}$-temperature programmed desorption $\left(\mathrm{CO}_{2}\right.$-TPD). The sample $(200 \mathrm{mg})$ was pretreated at $400^{\circ} \mathrm{C}$ for $60 \mathrm{~min}$ in $\mathrm{He}$, followed by cooling to $80^{\circ} \mathrm{C}$ under $\mathrm{He}$ flow and subsequent exposed to a $40 \% \mathrm{CO}_{2} / \mathrm{He}$ stream for 60 min. Flushing with $\mathrm{He}$ at $80^{\circ} \mathrm{C}$ for $3 \mathrm{~h}$ was applied to remove the adsorbed $\mathrm{CO}_{2}$, and TPD analysis was carried out from $80^{\circ} \mathrm{C}$ to $600^{\circ} \mathrm{C}$ at a heating rate of $10^{\circ} \mathrm{C} / \mathrm{min}$.

\subsection{Py-GC/MS system}

Pyrolysis experiments were conducted using in a micro-furnace single shot pyrolyzer (PY-2020iD, Frontier Laboratories, Japan) equipped with an auto-sampler (AS-1020E, Frontier Laboratories, Japan). For catalytic pyrolysis experiments, about $6 \mathrm{mg}$ of lignin was firstly introduced into a deactivated stainless steel sample cup, over which $6 \mathrm{mg}$ of the catalyst was put. For non-catalytic experiments, only $6 \mathrm{mg}$ of lignin was loaded. Subsequently, a little amount of quartz wool 
was loaded above the sample layer for each experiment to avoid powder spraying caused by carrier gas. The sample cup was then dropped into the pre-heated furnace under a flow of He as carrier gas.

Pyrolysis was performed for $1 \mathrm{~min}$, and the pyrolysis vapor was analyzed by a Thermo Ultra-Trace gas chromatograph (GC) with a Thermo DSQ II Mass spectrometer (MS) connected to the pyrolyzer. Chromatographic separation of the pyrolysis products was done with a (5\%-phenyl)-methylpolysiloxane non-polar column (HP-5MS, $60 \mathrm{~m} \times 0.25 \mathrm{~mm} \times 0.25 \mu \mathrm{m}$, Agilent Technologies, USA) with a carrier gas flow of $1.5 \mathrm{~mL} / \mathrm{min}$. The injector temperature was $280^{\circ} \mathrm{C}$ and a split ratio 1:40 were used. The GC oven was held at $40^{\circ} \mathrm{C}$ for $3 \mathrm{~min}$ and then heated to $300^{\circ} \mathrm{C}$ at $5^{\circ} \mathrm{C} / \mathrm{min}$ with a dwell time of $20 \mathrm{~min}$. The interface temperature between $\mathrm{GC}$ and $\mathrm{MS}$ was $280^{\circ} \mathrm{C}$, and the ion source temperature was $230^{\circ} \mathrm{C}$. Mass spectra were recorded under electron ionization $(70 \mathrm{eV})$ at the mass range from $45 \mathrm{~m} / \mathrm{z}$ to $300 \mathrm{~m} / \mathrm{z}$, using a scan rate of $1.0 \mathrm{~s} /$ decade. Identification of the pyrolysis compounds was carried out by comparison of their mass fragment with the National Institute of Standards and Technology (NIST) mass spectral library. Since the chromatographic peak area of a compound is considered linear with its quantity, a semi-quantitative estimation was used in this study that the yield and content of compounds could be revealed by peak area and peak area $\%$, respectively.

\section{Results and discussion}

\subsection{Characterization of lignin}

Lignin structure could directly affect pyrolysis product distribution, so that FT-IR was firstly used to investigate the bond structure of lignin. The FT-IR spectrum result is shown in Figure 2 and the corresponding assignments of bonds are given in Table 1 according to previous researches. The broad band around $3415 \mathrm{~cm}^{-1}$ was caused by $\mathrm{O}-\mathrm{H}$ stretching vibration. The bond at $2930 \mathrm{~cm}^{-1}$ and $1454 \mathrm{~cm}^{-1}$ were assigned respectively to $\mathrm{C}-\mathrm{H}$ stretching vibration and $\mathrm{C}-\mathrm{H}$ bending vibration attributable to the methyl and methylene groups. The peak at $1130 \mathrm{~cm}^{-1}$ had lower intensity than that at $1270 \mathrm{~cm}^{-1}$ indicating lower syringyl (S) unit content.
Moreover, strong signals at $1515 \mathrm{~cm}^{-1}$ and $1032 \mathrm{~cm}^{-1}$ also indicated a predominance of guaiacol $(\mathrm{G})$ units in this lignin, consisting with the $\mathrm{C}-\mathrm{H}$ out-of-plane deformation bands at $854 \mathrm{~cm}^{-1}$ and $817 \mathrm{~cm}^{-1}$ typical of $\mathrm{G}$ rings. FT-IR results suggested that the lignin used here was mainly composed of $\mathrm{G}$ type rings.

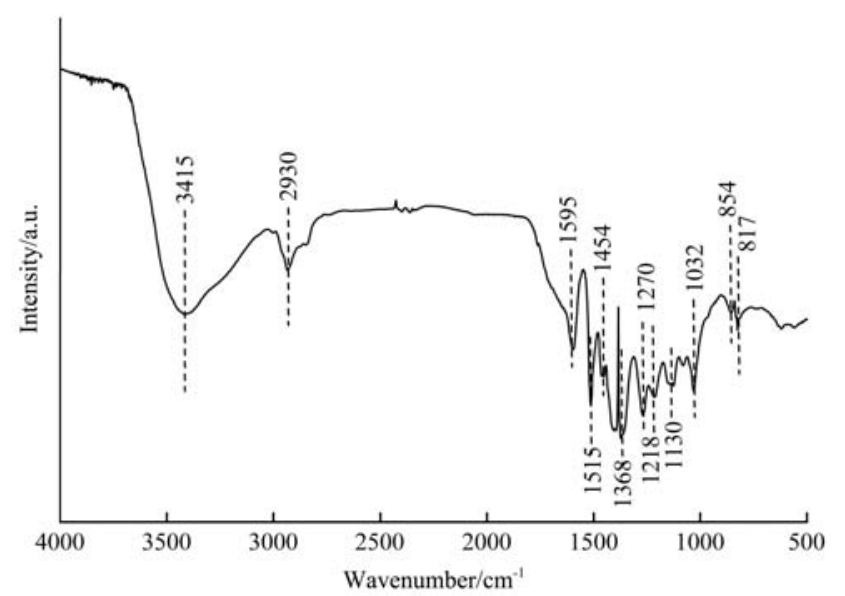

Figure 2 FT-IR spectrum of lignin

Table 1 Assignment of FT-IR spectrum of lignin

\begin{tabular}{rlcc}
\hline Peak $/ \mathrm{cm}^{-1}$ & \multicolumn{1}{c}{ Assignment } & $\begin{array}{c}\text { Miscanthus } \\
\text { Lignin }\end{array}{ }^{[20]} / \mathrm{cm}^{-1}$ & $\begin{array}{c}\text { Flax shives } \\
/ \mathrm{cm}^{-1}\end{array}$ \\
\hline 3415 & O-H stretching & 3435 & 3398 \\
2930 & C-H stretchingin $-\mathrm{CH}_{3}$ and $-\mathrm{CH}_{2}{ }^{-}$ & 2981 & 2933,2848 \\
1595 & Aromatic skeletal vibrations $(\mathrm{S}>\mathrm{G})$ & 1603 & 1593 \\
1515 & Aromatic skeletal vibrations $(\mathrm{G}>\mathrm{S})$ & 1508 & 1508 \\
1454 & C-H bendingin - $\mathrm{CH}_{3}$ and $-\mathrm{CH}_{2}{ }^{-}$ & 1463 & 1462 \\
1368 & $\begin{array}{l}\text { Aliphatic C-H stretching in } \mathrm{CH}_{3}, \\
\text { not in OMe }\end{array}$ & 1366 & 1369 \\
1270 & Guaiacol ring breathing & 1267 & 1265 \\
1218 & C-O stretch & 1230 & 1217 \\
1130 & Syringyl ring breathing & 1126 & 1122 \\
1032 & $\begin{array}{l}\text { Aromatic C-H in plane deformation } \\
\text { (G }>\mathrm{S})\end{array}$ & 1034 & 1030 \\
854,817 & $\begin{array}{l}\text { Aromatic C-H out-of-plane } \\
\text { deformation (G) }\end{array}$ & & 854,816 \\
\hline
\end{tabular}

Note: Peak assignments from Miscanthus lignin and flax shives are presented for comparison.

\subsection{Characterization of catalysts}

Since the crystal structure of catalysts played a role on the catalytic pyrolysis process of $\operatorname{lignin}^{[14]}$, XRD patterns of five catalysts used in this study are shown in Figure 3. The crystal structures of these five catalysts were significantly different from each other. The diffraction peaks in HZSM- 5 were mainly at $2 \theta=7.4^{\circ}-9.3^{\circ}$ and $22.5^{\circ}-24.8^{\circ}$. HZSM-5 had a typical diffraction pattern assigned to the MFI orthorhombic structure which consists of two channels of 10-membered rings and zigzag channels ${ }^{[22]}$. The pattern of $\mathrm{TiO}_{2}$ exhibited 
strong peaks at $2 \theta=24^{\circ}$ and $48^{\circ}$ corresponding to the anatase phase with tetragonal system ${ }^{[23]}$. The peaks were in good agreement with the standard spectrum (JCPDS NO.: 21-1272). The diffraction peaks in $\mathrm{ZrO}_{2}$ pattern were mainly at $2 \theta=24.0^{\circ}, 28.2^{\circ}, 31.5^{\circ}, 34.1^{\circ}$ and $50.0^{\circ}$ (JCPDS NO.: 37-1484), which exhibited monoclinic phase while no tetragonal phase was observed $^{[24]}$. The XRD pattern of $\mathrm{Mg}(\mathrm{Al}) \mathrm{O}$ exhibited the typical features of a mixed oxide of $\mathrm{Mg}(\mathrm{Al}) \mathrm{O}$ type. peaks at $2 \theta=42.8^{\circ}$ and $62.2^{\circ}$ corresponded to a periclase $\mathrm{MgO}$ or rather magnesia-alumina solid solution, while no obvious peaks of $\mathrm{Al}_{2} \mathrm{O}_{3}$ phase appeared suggesting $\mathrm{Al}^{3+}$ cations were well dispersed in the structure of $\mathrm{MgO}$ without formation of spinel species ${ }^{[25]}$. The XRD pattern of MCM-41 in Figure $3 b$ exhibited a characteristic intense (100) peak at $2 \theta=2.25^{\circ}$ and two higher order (110) and (200) reflections at $2 \theta=3.95^{\circ}$ and $4.60^{\circ}$, which could be indexed to the $p 6 \mathrm{~m}$ space group, indicating a hexagonal mesostructure ${ }^{[26,27]}$.

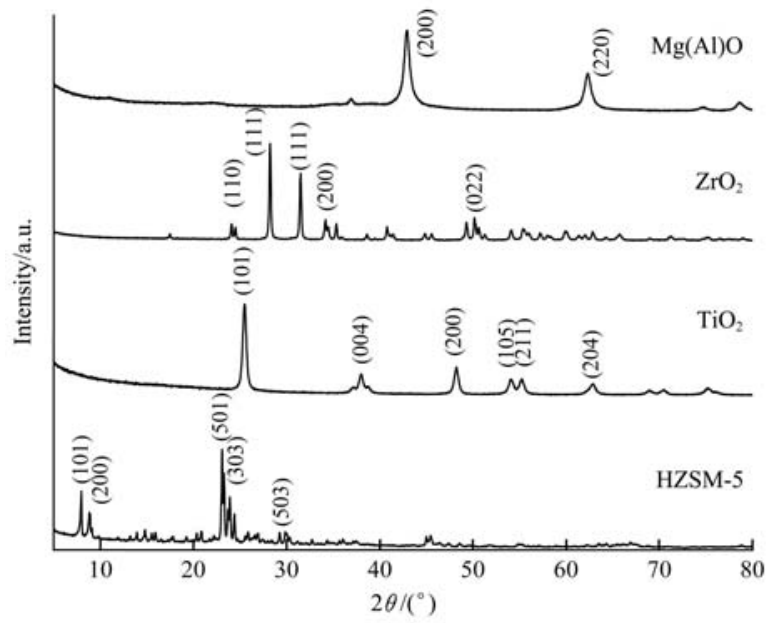

a. XRD patterns of $\mathrm{HZSM}-5, \mathrm{TiO}_{2}, \mathrm{ZrO}_{2}$ and $\mathrm{Mg}(\mathrm{Al}) \mathrm{O}$

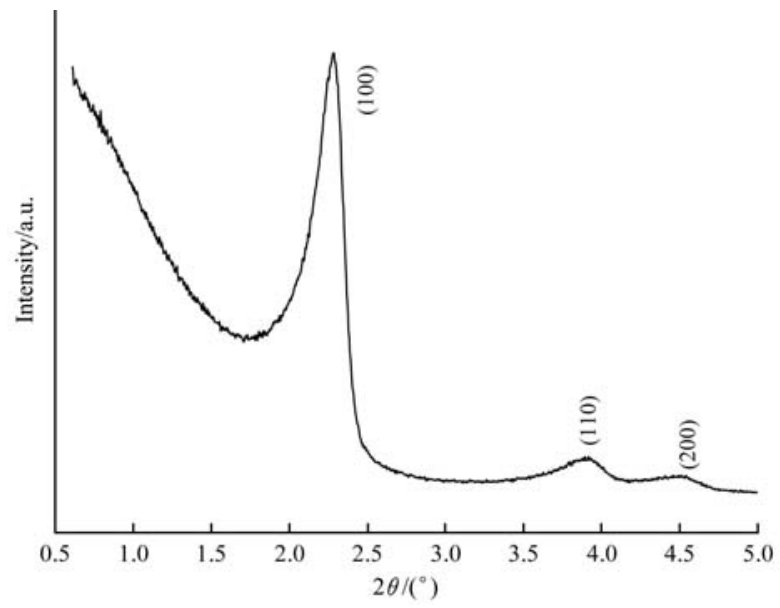

b. XRD patterns of MCM- 41

Figure 3 XRD patterns of $\mathrm{HZSM}-5, \mathrm{TiO}_{2}, \mathrm{ZrO}_{2}, \mathrm{Mg}(\mathrm{Al}) \mathrm{O}$ and MCM-41
Figure 4 shows the $\mathrm{NH}_{3}$-TPD results of five catalysts. The peaks appeared at $210^{\circ} \mathrm{C}-240^{\circ} \mathrm{C}$ were corresponded to the desorption of ammonia from the weak acid sites and the peaks at $434^{\circ} \mathrm{C}-590^{\circ} \mathrm{C}$ were assigned to the strong acid sites in the characterization of HZSM-5 and $\mathrm{Mg}(\mathrm{Al}) \mathrm{O}$. $\mathrm{TiO}_{2}$ also showed strong acid sites around $382^{\circ} \mathrm{C}$ and $561^{\circ} \mathrm{C}$, while the peak intensity was weak, indicating the relatively low amounts of acid sites. MCM-41 and $\mathrm{ZrO}_{2}$ showed no obvious peaks of TPD curves, indicating that these catalysts had very weak acid sites. The peak areas representing the amount of acid sites are summarized in Table 2. It is found that the total peak area of HZSM-5 was the largest among the five catalysts, while that of $\mathrm{ZrO}_{2}$ was the smallest one. $\mathrm{Mg}(\mathrm{Al}) \mathrm{O}$ was obtained by the thermal decomposition of hydrotalcites, which showed pairs of acid and basic sites. These pairs of acid and basic sites were obtained by the insertion of $\mathrm{Al}$ in the $\mathrm{MgO}$ lattice or the presence of $\mathrm{Mg}$ in the $\gamma-\mathrm{Al}_{2} \mathrm{O}_{3}$ lattice ${ }^{[28]}$. Accordingly, the basicity of $\mathrm{Mg}(\mathrm{Al}) \mathrm{O}$ was measured by $\mathrm{CO}_{2}$-TPD. As shown in Figure 5, three peaks were observed, two of which appeared at $195^{\circ} \mathrm{C}-281^{\circ} \mathrm{C}$ assigned to relatively weak basic sites and the other one at about $494^{\circ} \mathrm{C}$ assigned to strong basic sites.

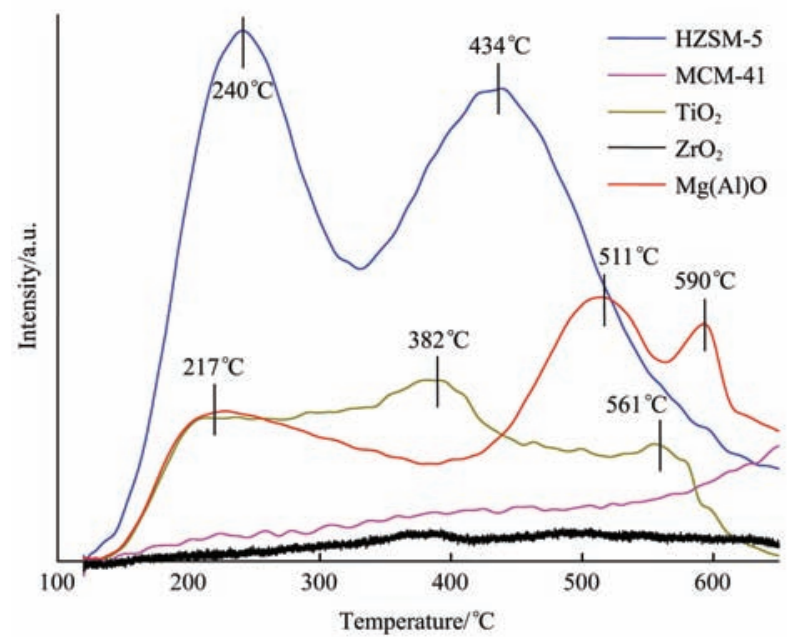

Figure $4 \mathrm{NH}_{3}-\mathrm{TPD}$ profile of five catalysts used in this study

Table 2 Physical-chemical properties of the catalysts

\begin{tabular}{cccc}
\hline Catalysts & $\begin{array}{c}\mathrm{BET} \text { surface area } \\
/ \mathrm{m}^{2} \cdot \mathrm{g}^{-1}\end{array}$ & $\begin{array}{c}\text { Total pore volume } \\
/ \mathrm{cm}^{3} \cdot \mathrm{g}^{-1}\end{array}$ & $\begin{array}{c}\text { Total peak area of } \\
\mathrm{NH}_{3} \text {-TPD }\end{array}$ \\
\hline $\mathrm{HZSM}-5$ & 393.514 & 0.21 & 3486 \\
$\mathrm{MCM}-41$ & 1067.66 & 1.03 & 524 \\
$\mathrm{TiO}_{2}$ & 71.83 & 0.44 & 1285 \\
$\mathrm{ZrO}_{2}$ & 5.49 & 0.03 & 200 \\
$\mathrm{MgAlO}$ & 126.74 & 0.58 & 1666 \\
\hline
\end{tabular}




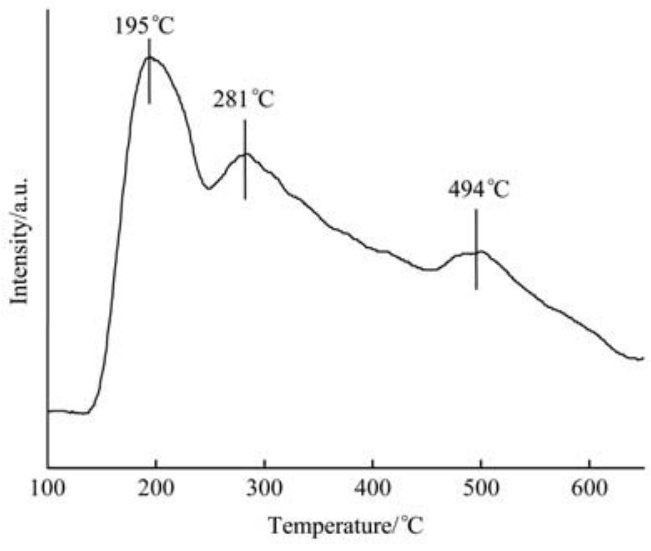

Figure $5 \quad \mathrm{CO}_{2}-\mathrm{TPD}$ profile of $\mathrm{Mg}(\mathrm{Al}) \mathrm{O}$ catalyst

The porosity of the five catalysts is illustrated in Figure 6, and the surface area and total pore volume are

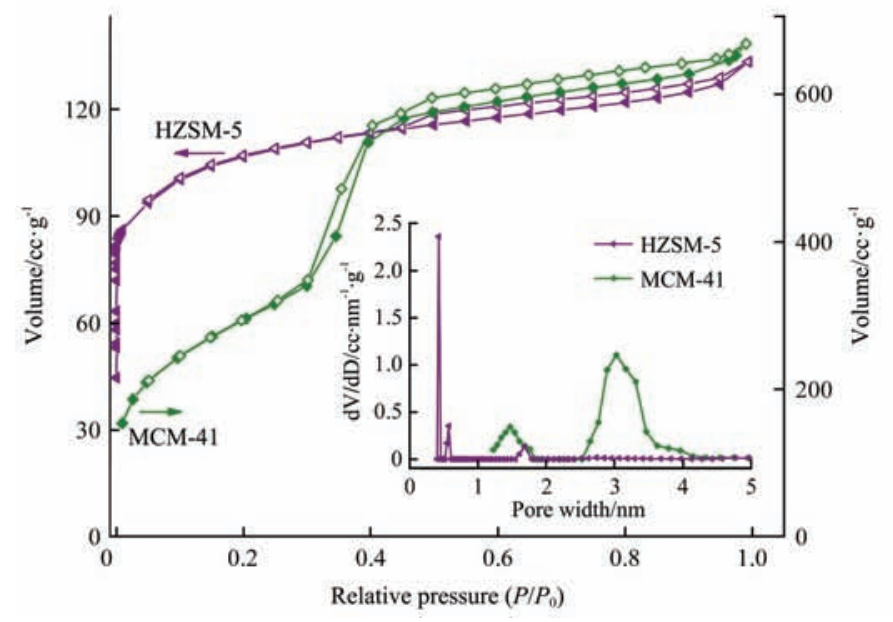

a. HZSM-5 and MCM-41 listed in Table 2. Among the five catalysts, only HZSM-5 showed a dominant peak at $0.43 \mathrm{~nm}$ and another peak at $0.58 \mathrm{~nm}$, indicating a microporous structure. MCM-41 showed a pore size distribution mainly centered at $3.04 \mathrm{~nm}$ corresponding to mesoporous structure. MCM-41 had the largest BET surface area and total pore volume among the five zeolite catalysts $\left(1067.66 \mathrm{~m}^{2} / \mathrm{g}\right.$ for surface area and $1.03 \mathrm{~m}^{3} / \mathrm{g}$ for total pore volume). Both $\mathrm{TiO}_{2}$ and $\mathrm{Mg}(\mathrm{Al}) \mathrm{O}$ showed a board pore size distribution ranged from $3.5 \mathrm{~nm}$ to $32 \mathrm{~nm}$, indicating the existing of irregular mesoporous structure. $\mathrm{ZrO}_{2}$ presented a non-porous characteristic with a BET surface area of only $5.49 \mathrm{~m}^{2} / \mathrm{g}$.

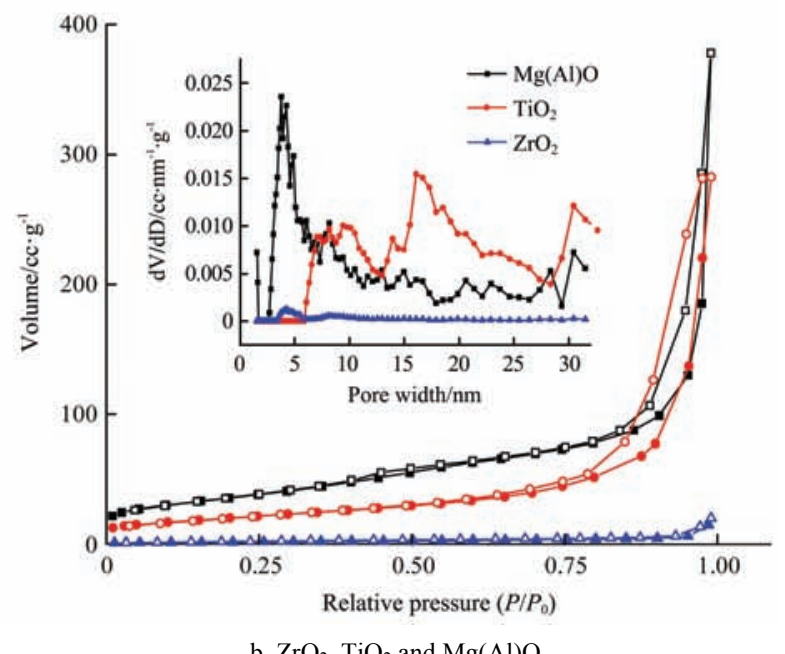

b. $\mathrm{ZrO}_{2}, \mathrm{TiO}_{2}$ and $\mathrm{Mg}(\mathrm{Al}) \mathrm{O}$

Figure 6 Adsorption/desorption isotherms and pore size distribution of studied catalysts

\subsection{Effect of temperature on lignin pyrolysis}

The products of lignin fast pyrolysis included non-condensable gas, volatile compounds and non-volatile oligomers. In the present py-GC/MS system, only volatile compounds could be analyzed, and the indentified compounds were categorized into five categories: aromatic hydrocarbons, phenol-type compounds (phenols), catechol-type compound (catechols), alkoxyl-type compounds (alkoxyls) and polyaromatics. Alkoxyl-type compounds were composed of guaiacol-type compounds and aromatic hydrocarbon alkoxyls. Large molecular weight like sterols and non-indentified compounds were classified as others. In order to know the connection between lignin structure and pyrolysis products, lignin was firstly pyrolyzed at different temperatures without catalyst. The product distribution for non-catalytic pyrolysis of lignin at $400^{\circ} \mathrm{C}, 500^{\circ} \mathrm{C}$ and $600^{\circ} \mathrm{C}$ is shown in Table 3 and Figure 7. It is found that the total peak area increased significantly from $3.66 \times 10^{9}$ at $400^{\circ} \mathrm{C}$ to $1.68 \times 10^{10}$ at $500^{\circ} \mathrm{C}$ and then slightly decreased to $1.45 \times 10^{10}$ at $600^{\circ} \mathrm{C}$ with the increased pyrolysis temperature, indicating that high temperature was beneficial to increasing the yield of volatile liquid. Similar observation was made by Latridis et al. ${ }^{[29]}$ Lignin pyrolysis happened in a wide temperature range which started around $160^{\circ} \mathrm{C}$. Linkages between the lignin units like $\alpha$-O-4 were first cleaved between $200^{\circ} \mathrm{C}$ and $400^{\circ} \mathrm{C}$ due to the relatively low bond dissociation energy, which produced the alkoxyls (e.g. guaiacol, 4-methyl-guaiacol, and vanillin) as the major products. With the increase of temperature, the amount of alkoxyls increased obviously from $2.31 \times 10^{9}$ to $1.02 \times 10^{10}$. Due to the lignin used in this study was softwood lignin, the alkoxyls obtained 
were mainly the G types, in accordance with the results of

FT-IR. The aromatic hydrocarbons were only detected at $600^{\circ} \mathrm{C}$, while its amount (peak area: $2.53 \times 10^{7}$ ) was relatively low. Furthermore, pyrolysis products became more complicated at relatively high temperatures due to more complicated depolymerization process and secondary reactions. The amount of 1,2-Benzenediol was found to be increased from 0 to $1.40 \times 10^{8}$ with the temperature elevated from $400^{\circ} \mathrm{C}$ to $600^{\circ} \mathrm{C}$, while the amount of 3-methyl-1,2-Benzenediol increased from 0 to $9.02 \times 10^{7}$. It could be attributed to that secondary decomposition occurred at high temperatures resulting in the conversion of guaiacols into catechols ${ }^{[30]}$.

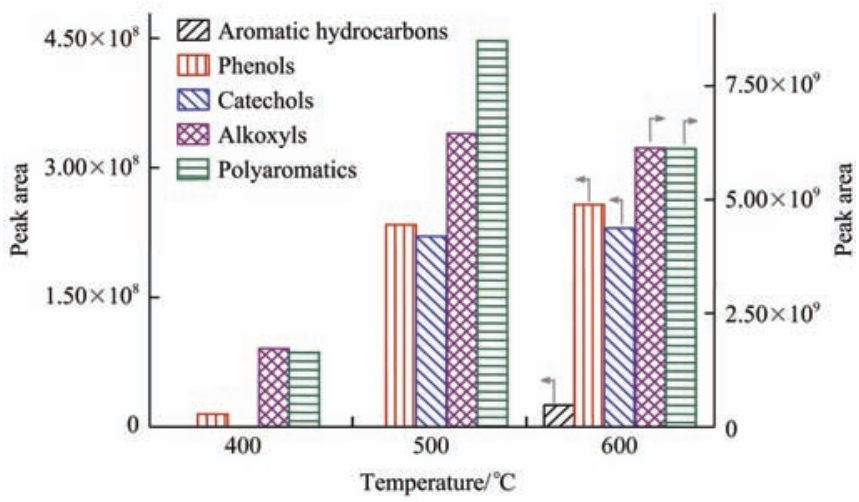

Figure 7 Effect of temperatures on the production distributions

Table 3 Product distribution for non-catalytic pyrolysis of lignin at different temperatures

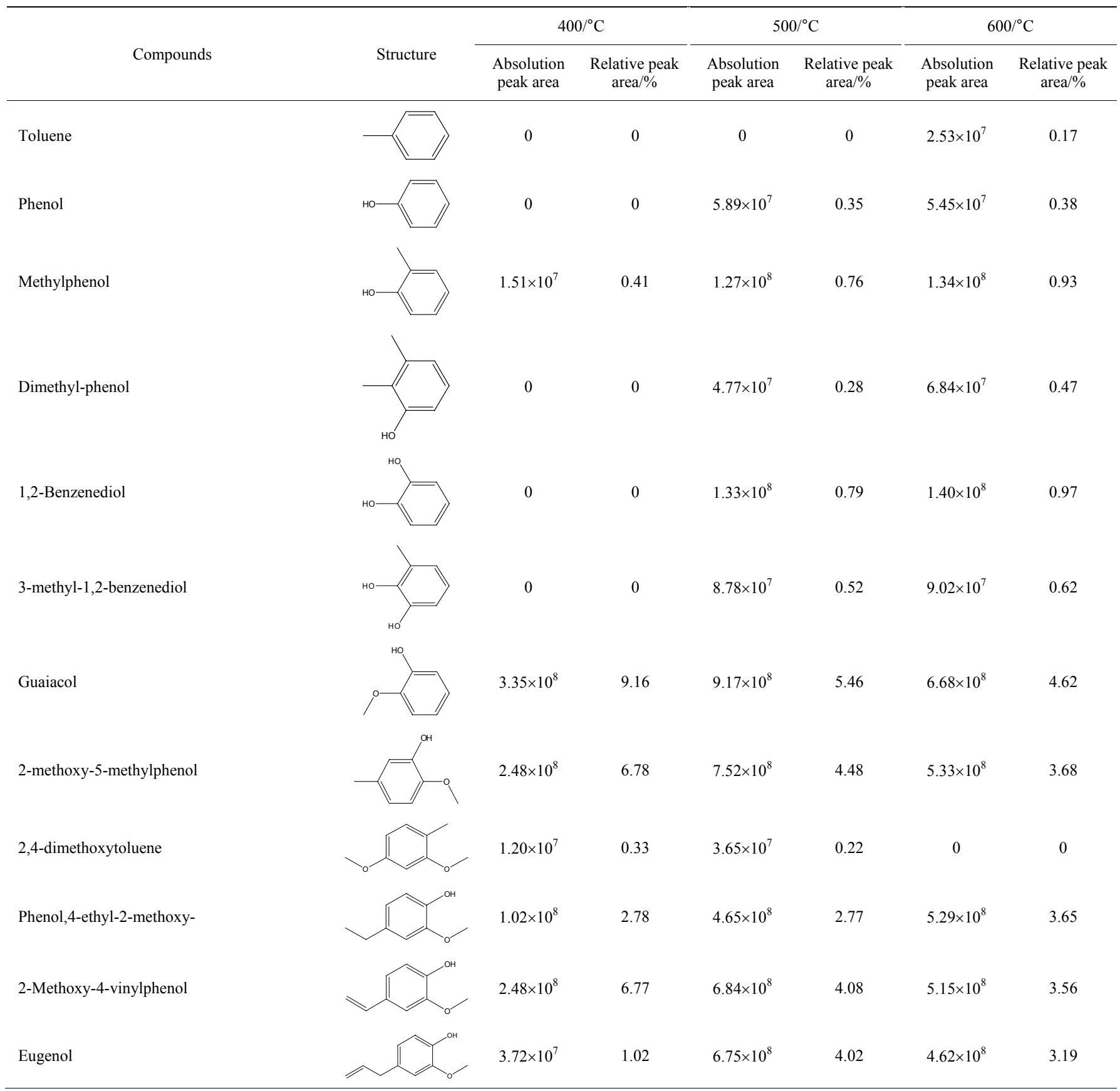




\begin{tabular}{|c|c|c|c|c|c|c|c|}
\hline \multirow[b]{2}{*}{ Compounds } & \multirow[b]{2}{*}{ Structure } & \multicolumn{2}{|c|}{$400 /{ }^{\circ} \mathrm{C}$} & \multicolumn{2}{|c|}{$500 /{ }^{\circ} \mathrm{C}$} & \multicolumn{2}{|c|}{$600 /{ }^{\circ} \mathrm{C}$} \\
\hline & & $\begin{array}{c}\text { Absolution } \\
\text { peak area }\end{array}$ & $\begin{array}{l}\text { Relative peak } \\
\text { area/\% }\end{array}$ & $\begin{array}{c}\text { Absolution } \\
\text { peak area }\end{array}$ & $\begin{array}{l}\text { Relative peak } \\
\quad \text { area/\% }\end{array}$ & $\begin{array}{c}\text { Absolution } \\
\text { peak area }\end{array}$ & $\begin{array}{c}\text { Relative peak } \\
\text { area/\% }\end{array}$ \\
\hline Vanilin & & $1.15 \times 10^{8}$ & 3.14 & $4.43 \times 10^{8}$ & 2.64 & $4.28 \times 10^{8}$ & 2.96 \\
\hline Phenol,2-methoxy-4-(1-propenyl)- & & $1.34 \times 10^{7}$ & 3.67 & 0 & 0 & 0 & 0 \\
\hline Phenol,2-methoxy-4-propyl- & & $2.09 \times 10^{7}$ & 0.57 & 0 & 0 & 0 & 0 \\
\hline 2-Propanone,1-(4-hydroxy-3-methoxyphenyl)- & & $4.92 \times 10^{7}$ & 1.35 & $2.23 \times 10^{8}$ & 1.33 & $2.36 \times 10^{8}$ & 1.63 \\
\hline Vanillic acid & & 0 & 0 & 0 & 0 & $1.68 \times 10^{8}$ & 1.16 \\
\hline Benzene,1,2-dimethoxy-4-propyl- & & $2.64 \times 10^{7}$ & 0.72 & $1.49 \times 10^{8}$ & 0.89 & $1.79 \times 10^{8}$ & 1.23 \\
\hline Benzenepropanol,4-hydroxy-3-methoxy- & & $1.45 \times 10^{7}$ & 3.96 & $7.19 \times 10^{8}$ & 4.29 & $9.60 \times 10^{8}$ & 6.63 \\
\hline Phenol,4-(3-hydroxy-1-propenyl)-2-methoxy- & & $1.79 \times 10^{8}$ & 4.90 & $1.10 \times 10^{9}$ & 6.56 & $1.13 \times 10^{9}$ & 7.80 \\
\hline Polyaromatics & - & $1.6 \times 10^{9}$ & 44.76 & $8.49 \times 10^{9}$ & 50.62 & $6.12 \times 10^{9}$ & 42.30 \\
\hline Others & - & $1.6 \times 10^{8}$ & 4.41 & $1.38 \times 10^{9}$ & 8.23 & $1.70 \times 10^{9}$ & 11.77 \\
\hline
\end{tabular}

3.4 Production distribution from catalytic pyrolysis of lignin

To investigate the performances of catalysts on the product distribution of lignin pyrolysis, catalytic pyrolysis of lignin with zeolites (HZSM-5, MCM-41) and metal oxides $\left(\mathrm{TiO}_{2}, \mathrm{ZrO}_{2}, \mathrm{Mg}(\mathrm{Al}) \mathrm{O}\right)$ were conducted. Since the aromatic hydrocarbons were produced at $600^{\circ} \mathrm{C}$, the catalytic pyrolysis was conducted at the same temperature. Table 4 and Figure 8 show the product distribution from catalytic pyrolysis of lignin with HZSM-5 and MCM-41. In the first column of the Table 4 , non-catalytic pyrolysis is listed for comparison of the catalysts effect on the product distribution of the volatile liquid fraction. It is found that the total amount was both decreased with the two zeolite catalysts. In the presence of HZSM-5 catalysts, the amount of alkoxyls decreased from $6.13 \times 10^{9}$ to $5.35 \times 10^{9}$, and aromatic hydrocarbons significantly increased from $2.53 \times 10^{7}$ to $2.24 \times 10^{8}$. Previous studies showed that HZSM-5 zeolite contained Bronsted acid sites that were favorable for the formation of aromatic hydrocarbons ${ }^{[31-33]}$. Li et al. ${ }^{[34]}$ also obtained similar results and demonstrated that as the acidity of HZSM-5 increased, the yields of aromatic hydrocarbons increased. In addition to acidity, pore structure could also affect the catalytic process significantly due to shape selectivity ${ }^{[35]}$. However, most oxygenates derived from lignin pyrolysis had a larger dimension than the pore size of HZSM-5, resulting that oxygenates could only be converted at the external surface, in which only existed a small fraction of acid sites ${ }^{[18]}$. This might be the reason for the relatively low yield of aromatic hydrocarbons with HZSM-5 in this study. Comparing with the non-catalytic pyrolysis, the peak area decreased obviously from $1.45 \times 10^{10}$ to $3.65 \times 10^{9}$, indicating the yield of volatile liquid fraction decreased with the use of MCM-41. Iliopoulou et al. ${ }^{[36]}$ observed polycyclic aromatic hydrocarbons (PAHs) and heavy compounds were significantly increased with MCM-41 as catalyst, compared to the non-catalytic experiment, due to its high thermal cracking activity. But it could not be able to further convert these heavy compounds to 
hydrocarbons due to the lack of acid site. In our study, polyaromatics were not detected resulting in the decrease of volatile liquid yield. This might be attributed to the further polymerization of heavy fraction resulting in the formation of non-volatile oligomers, which could not be detected in our system.

Table 4 Product distribution for pyrolysis of lignin with different zeolites at $600^{\circ} \mathrm{C}$

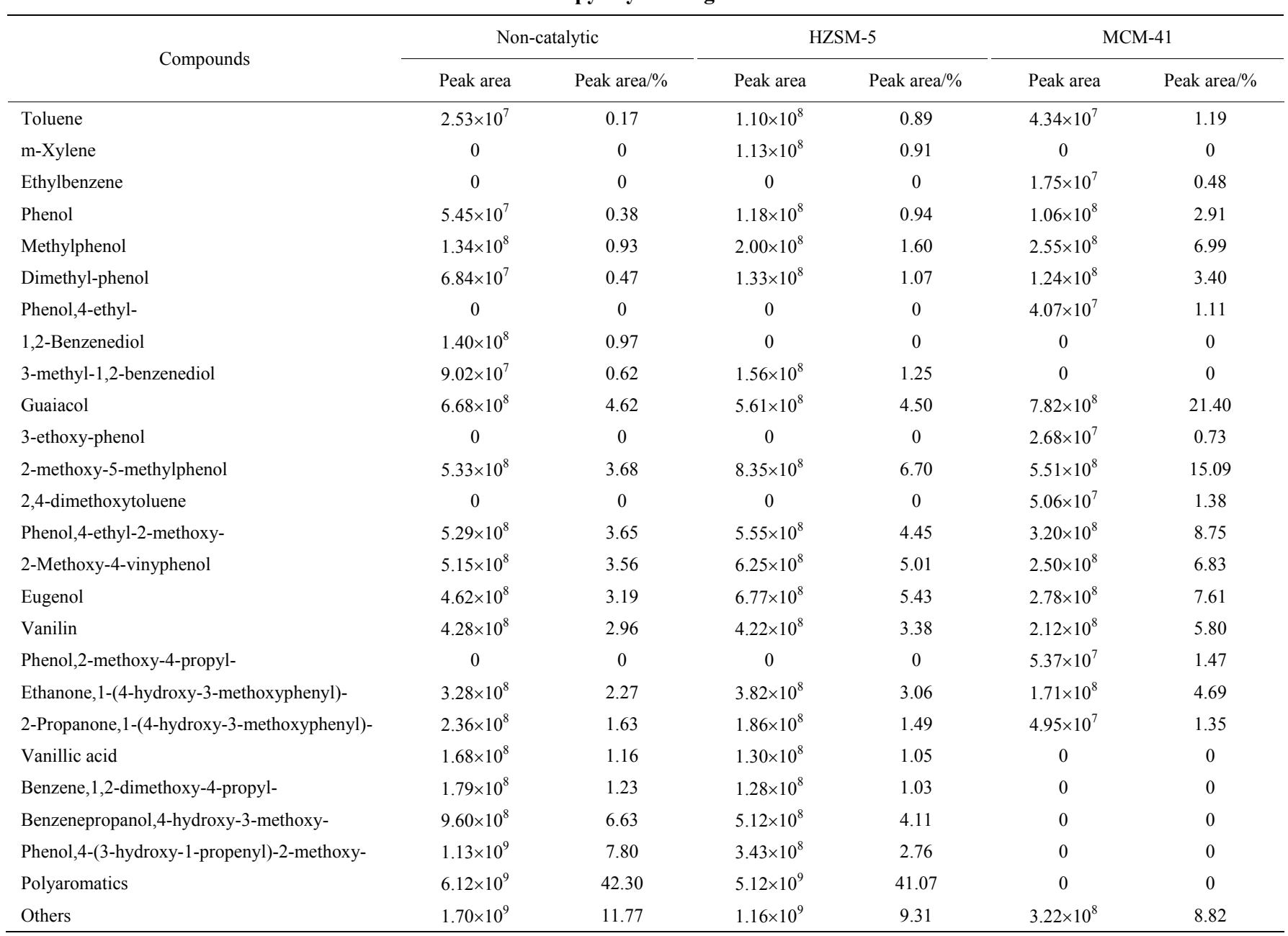

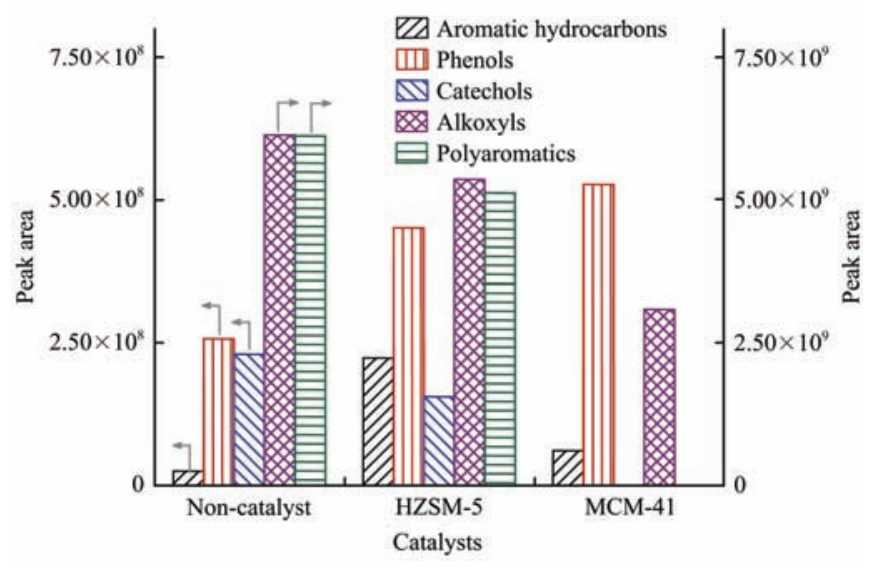

Figure 8 Effect of the zeolite catalysts on the production distributions

Table 5 and Figure 9 show the product distribution from catalytic pyrolysis of lignin with $\mathrm{TiO}_{2}, \mathrm{ZrO}_{2}$ and $\mathrm{Mg}(\mathrm{Al}) \mathrm{O}$. In the presence of $\mathrm{TiO}_{2}$, the mount of aromatic hydrocarbons increased from $2.53 \times 10^{7}$ to $6.55 \times 10^{7}$ and phenols increased from $2.57 \times 10^{8}$ to
$1.24 \times 10^{9}$. The highest amount of phenol-type compounds was achieved with the use of $\mathrm{TiO}_{2}$. This might be attributed to the complete and incomplete deoxygenation of alkoxyls, since the amount of alkoxyls decreased from $6.13 \times 10^{9}$ to $3.87 \times 10^{9}$. The highest alkoxyls yield was obtained in the presence of $\mathrm{ZrO}_{2}$, while the aromatic hydrocarbon yield was barely changed. Due to the much lower surface area, $\mathrm{ZrO}_{2}$ could lead to high yield of oxygenats and be less effective on deoxygenation than $\mathrm{TiO}_{2}{ }^{[37]}$. This result was similar to Kaewpengkrow et al. ${ }^{[38]}$ who studied the effect of catalyst supporters including $\mathrm{Al}_{2} \mathrm{O}_{3}, \mathrm{ZrO}_{2}, \mathrm{TiO}_{2}$ (rutil) and $\mathrm{TiO}_{2}$ (anatase) on upgrading the pyrolysis vapors, and found that the yield of aromatic hydrocarbons of $\mathrm{TiO}_{2}$ (anatase) was higher than $\mathrm{ZrO}_{2}$ and $\mathrm{TiO}_{2}$ (rutil). Pyrolysis with acidic catalysts was prone to form coke via oligomerization, so that catalysts owing basic sites were 
expected to reduce coke formation during pyrolysis process. $\mathrm{Mg}(\mathrm{Al}) \mathrm{O}$ catalyst with both acidic and base sites was selected in comparison to acidic catalyst. The amount of aromatic hydrocarbons increased from $2.53 \times 10^{7}$ to $5.09 \times 10^{7}$. However, the $\mathrm{Mg}(\mathrm{Al}) \mathrm{O}$ catalyst resulted in an obvious reduction in the yield of volatile liquid fraction. The peak area of alkoxyls sharply decreased from $6.13 \times 10^{9}$ to $1.34 \times 10^{9}$, and that of polyaromatics also decreased from $6.12 \times 10^{9}$ to $9.65 \times 10^{8}$. Auta et al. ${ }^{[39]}$ also obtained the similar results with $\mathrm{MgO}$ catalyst that the yields of liquid decreased while the yields of gas and char increased. Wang et al. ${ }^{[0]}$ also investigated the catalytic pyrolysis with base catalyst $(\mathrm{CaO})$. The residue yield was much higher than the non-catalytic run at $600^{\circ} \mathrm{C}$, which meant to the lower yield of liquid products.

Table 5 Product distribution for pyrolysis of lignin with different metal oxides at $600^{\circ} \mathrm{C}$

\begin{tabular}{|c|c|c|c|c|c|c|c|c|}
\hline \multirow{2}{*}{ Compounds } & \multicolumn{2}{|c|}{ Non-catalytic } & \multicolumn{2}{|c|}{$\mathrm{TiO}_{2}$} & \multicolumn{2}{|c|}{$\mathrm{ZrO}_{2}$} & \multicolumn{2}{|c|}{$\mathrm{MgAlO}$} \\
\hline & Peak area & Peak area $/ \%$ & Peak area & Peak area $/ \%$ & Peak area & Peak area/\% & Peak area & Peak area/\% \\
\hline Benzene & 0 & 0 & $2.19 \times 10^{7}$ & 0.20 & 0 & 0 & 0 & 0 \\
\hline Toluene & $2.53 \times 10^{7}$ & 0.17 & $3.54 \times 10^{7}$ & 0.32 & $2.32 \times 10^{7}$ & 0.13 & $3.72 \times 10^{7}$ & 1.05 \\
\hline m-Xylene & 0 & 0 & $8.19 \times 10^{6}$ & 0.07 & $7.80 \times 10^{6}$ & 0.04 & $1.37 \times 10^{7}$ & 0.39 \\
\hline Phenol & $5.45 \times 10^{7}$ & 0.38 & $2.60 \times 10^{8}$ & 2.32 & $8.90 \times 10^{7}$ & 0.50 & $7.74 \times 10^{7}$ & 2.18 \\
\hline Methylphenol & $1.34 \times 10^{8}$ & 0.93 & $5.60 \times 10^{8}$ & 5.00 & $1.85 \times 10^{8}$ & 1.03 & $1.95 \times 10^{8}$ & 5.52 \\
\hline Dimethyl-phenol & $6.84 \times 10^{7}$ & 0.47 & $2.03 \times 10^{8}$ & 1.81 & $7.70 \times 10^{7}$ & 0.43 & $1.49 \times 10^{8}$ & 4.20 \\
\hline Phenol,4-ethyl- & 0 & 0 & $1.65 \times 10^{8}$ & 1.48 & $5.00 \times 10^{7}$ & 0.28 & 0 & 0 \\
\hline Phenol,3-ethyl-5-methyl- & 0 & 0 & $5.20 \times 10^{7}$ & 0.46 & 0 & 0 & 0 & 0 \\
\hline 1,2-Benzenediol & $1.40 \times 10^{8}$ & 0.97 & $1.31 \times 10^{8}$ & 1.17 & $3.42 \times 10^{8}$ & 1.91 & 0 & 0 \\
\hline 3-methyl-1,2-benzenediol & $9.02 \times 10^{7}$ & 0.62 & 0 & 0 & $1.25 \times 10^{8}$ & 0.70 & 0 & 0 \\
\hline Guaiacol & $6.68 \times 10^{8}$ & 4.62 & $2.48 \times 10^{8}$ & 2.21 & $7.81 \times 10^{8}$ & 4.35 & $2.45 \times 10^{8}$ & 6.91 \\
\hline 2-methoxy-5-methylphenol & $5.33 \times 10^{8}$ & 3.68 & $3.06 \times 10^{8}$ & 2.73 & $8.41 \times 10^{8}$ & 4.69 & $3.22 \times 10^{8}$ & 9.08 \\
\hline 2,4-dimethoxytoluene & 0 & 0 & 0 & 0 & $3.40 \times 10^{7}$ & 0.19 & $4.10 \times 10^{7}$ & 1.16 \\
\hline Phenol,4-ethyl-2-methoxy- & $5.29 \times 10^{8}$ & 3.65 & $4.04 \times 10^{8}$ & 3.60 & $6.41 \times 10^{8}$ & 3.57 & $1.63 \times 10^{8}$ & 4.60 \\
\hline 2-Methoxy-4-vinyphenol & $5.15 \times 10^{8}$ & 3.56 & $3.46 \times 10^{8}$ & 3.09 & $6.72 \times 10^{8}$ & 3.75 & $2.10 \times 10^{8}$ & 5.93 \\
\hline Eugenol & $4.62 \times 10^{8}$ & 3.19 & $4.66 \times 10^{8}$ & 4.16 & $6.41 \times 10^{8}$ & 3.57 & $1.82 \times 10^{8}$ & 5.14 \\
\hline Vanilin & $4.28 \times 10^{8}$ & 2.96 & $3.17 \times 10^{8}$ & 2.83 & $6.16 \times 10^{8}$ & 3.43 & $8.97 \times 10^{7}$ & 2.53 \\
\hline Ethanone,1-(4-hydroxy-3-methoxyphenyl)- & $3.28 \times 10^{8}$ & 2.27 & $3.24 \times 10^{8}$ & 2.89 & $4.27 \times 10^{8}$ & 2.38 & 0 & 0 \\
\hline 2-Propanone,1-(4-hydroxy-3-methoxyphenyl)- & $2.36 \times 10^{8}$ & 1.63 & $2.47 \times 10^{8}$ & 2.20 & $3.30 \times 10^{8}$ & 1.84 & $3.05 \times 10^{7}$ & 0.86 \\
\hline Vanillic acid & $1.68 \times 10^{8}$ & 1.16 & 0 & 0 & $2.09 \times 10^{8}$ & 1.16 & 0 & 0 \\
\hline Benzene,1,2-dimethoxy-4-propyl- & $1.79 \times 10^{8}$ & 1.23 & $1.62 \times 10^{8}$ & 1.45 & $2.87 \times 10^{8}$ & 1.60 & 0 & 0 \\
\hline Benzenepropanol,4-hydroxy-3-methoxy- & $9.60 \times 10^{8}$ & 6.63 & $7.62 \times 10^{8}$ & 6.80 & $1.18 \times 10^{9}$ & 6.58 & 0 & 0 \\
\hline Others & $1.70 \times 10^{9}$ & 11.77 & $3.01 \times 10^{9}$ & 26.88 & $1.6 \times 10^{9}$ & 8.99 & $7.6 \times 10^{8}$ & 21.51 \\
\hline
\end{tabular}

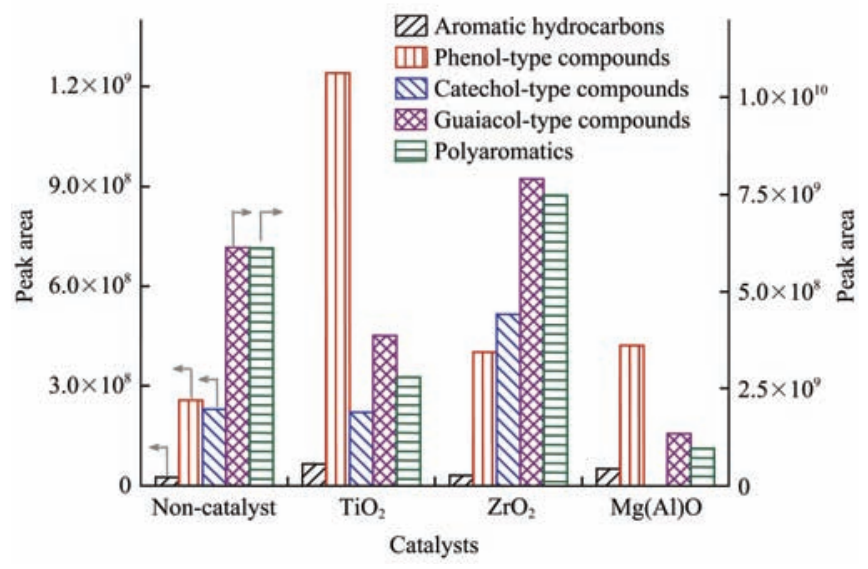

Figure 9 Effect of the metal oxides on the production distributions

\section{Conclusion}

Fast pyrolysis of lignin was carried out by py-GC/MS method to investigate the product distribution influenced by both temperature and catalyst. The predominant products of fast pyrolysis of lignin were alkoxyls, resulting from the cleavage of linkages between the lignin units like $\alpha$-O-4. These alkoxyls products were mainly $\mathrm{G}$ type, which were in accordance with the lignin structure. For non-catalytic pyrolysis of lignin, the highest amount of volatile fraction was obtained at $500^{\circ} \mathrm{C}$, while the highest amount of aromatic hydrocarbons was 
obtained at $600^{\circ} \mathrm{C}$. For catalytic pyrolysis of lignin, the amount of total volatile fraction changed in a wide range over catalysts with different structures and acid-base properties. The maximum production of aromatic hydrocarbons was achieved in the presence of HZSM-5, and the highest yield of liquid fraction was obtained in the addition of $\mathrm{ZrO}_{2}$. The base catalyst, $\mathrm{Mg}(\mathrm{Al}) \mathrm{O}$, led to the reduction of liquid yield by increasing the yield of oligomers and coke. Generally, the shape selectivity effect is in favor of the formation of aromatic hydrocarbons, but it has limited effect on the catalytic pyrolysis of lignin. Additionally, appropriate acid sites are needed for deoxygenation of oxygenates.

\section{Acknowledge}

This work was supported by The National Natural Science Foundation of China (51536009), NSFC (Natural Science Foundation of China) project (51476175), National Basic Research Program of China (2013CB228105), Chinese Academy of Sciences "one hundred talented plan", and Beijing Municipal Key Discipline of Biomass Engineering.

\section{[References]}

[1] Liaw S S, Perez V H, Zhou S, Rodriguez-Justo O, Garcia-Perez M. Py-GC/MS studies and principal component analysis to evaluate the impact of feedstock and temperature on the distribution of products during fast pyrolysis. Journal of Analytical and Applied Pyrolysis, 2014; 109: 140-151.

[2] Anex R P, Aden A, Kazi F K, Fortman J, Swanson R M, Wright M M, et al. Techno-economic comparison of biomass-to-transportation fuels via pyrolysis, gasification, and biochemical pathways. Fuel, 2010; 89: S29-S35.

[3] Aho A, Kumar N, Eränen K, Salmi T, Hupa M, Murzin D Y. Catalytic pyrolysis of woody biomass in a fluidized bed reactor: influence of the zeolite structure. Fuel, 2008; 87(12): 2493-2501.

[4] Zhang H, Xiao R, Huang H, Xiao G. Comparison of non-catalytic and catalytic fast pyrolysis of corncob in a fluidized bed reactor. Bioresource Technology, 2009; 100(3): 1428-1434.

[5] Carlson T R, Tompsett G A, Conner W C, Huber G W. Aromatic production from catalytic fast pyrolysis of biomass-derived feedstocks. Topics in Catalysis, 2009; 52(3): 241-252.
[6] Karanjkar P U, Coolman R J, Huber G W, Blatnik M T, Almalkie S, Bruyn Kops S M, et al. Production of aromatics by catalytic fast pyrolysis of cellulose in a bubbling fluidized bed reactor. AIChE Journal, 2014; 60(4): $1320-1335$.

[7] Zhu X, Lu Q, Li W, Zhang D. Fast and catalytic pyrolysis of xylan: Effects of temperature and M/HZSM-5 (M=Fe, Zn) catalysts on pyrolytic products. Frontiers of Energy and Power Engineering in China, 2010; 4(3): 424-429.

[8] Kim S S, Jun B R, Park S H, Jeon J K, Suh D J, Kim T W, et al. Catalytic upgrading of xylan over mesoporous y catalyst. Journal of Nanoscience and Nanotechnology, 2014; 14(4): 2925-2930.

[9] Guo X, Wang S, Zhou Y, Luo Z. Catalytic pyrolysis of xylan-based hemicellulose over zeolites. Int $\mathrm{J}$ Energy Environ, 2011; 5(4): 137-142.

[10] Kloekhorst A, Wildschut J, Heeres H J. Catalytic hydrotreatment of pyrolytic lignins to give alkylphenolics and aromatics using a supported $\mathrm{Ru}$ catalyst. Catalysis Science \& Technology, 2014; 4(8): 2367-2677.

[11] Okuda K, Umetsu M, Takami S, Adschiri T. Disassembly of lignin and chemical recovery-rapid depolymerization of lignin without char formation in water-phenol mixtures. Fuel Processing Technology, 2004; 85(8): 803-813.

[12] Li C Z, Zhao X C, Wang A Q, Huber G W, Zhang T. Catalytic transformation of lignin for the production of chemicals and fuels. Chemical Reviews, 2015; 115(21): 11559-11624.

[13] Neumann G T, Pimentel B R, Rensel D J, Hicks J C. Correlating lignin structure to aromatic products in the catalytic fast pyrolysis of lignin model compounds containing $\beta-\mathrm{O}-4$ linkages. Catalysis Science \& Technology, 2014; 4(11): 3953-3963.

[14] Shen D, Zhao J, Xiao R, Gu S. Production of aromatic monomers from catalytic pyrolysis of black-liquor lignin. Journal of Analytical and Applied Pyrolysis, 2015; 111: $47-54$.

[15] Azadi P, Inderwildi O R, Farnood R, King D A. Liquid fuels, hydrogen and chemicals from lignin: A critical review. Renewable and Sustainable Energy Reviews, 2013; 21: 506-523.

[16] Thring R W, Katikaneni S P, Bakhshi N N. The production of gasoline range hydrocarbons from Alcell ${ }^{\circledR}$ lignin using HZSM-5 catalyst. Fuel Processing Technology, 2000; 62(1): $17-30$.

[17] Mullen C A, Boateng A A. Catalytic pyrolysis-GC/MS of lignin from several sources. Fuel Processing Technology, 2010; 91(11): 1446-1458.

[18] Yu Y, Li X, Su L, Zhang Y, Wang Y, Zhang H. The role of shape selectivity in catalytic fast pyrolysis of lignin with 
zeolite catalysts. Applied Catalysis A: General, 2012; 447: $115-123$.

[19] Adhikari S, Srinivasan V, Fasina O. Catalytic pyrolysis of raw and thermally treated lignin using different acidic zeolites. Energy \& Fuels, 2014; 28(7): 4532-4538.

[20] El Hage R, Brosse N, Chrusciel L, Sanchez C, Sannigrahi P, Ragauskas A. Characterization of milled wood lignin and ethanol organosolv lignin from miscanthus. Polymer Degradation and Stability, 2009; 94(10): 1632-1638.

[21] Monteil-Rivera F, Phuong M, Ye M, Halasz A, Hawari J. Isolation and characterization of herbaceous lignins for applications in biomaterials. Industrial Crops and Products, 2013; 41: 356-364.

[22] Kong X, Li X, Wu S, Zhang X, Liu J. Efficient conversion of cotton stalks over a Fe modified HZSM-5 catalyst under microwave irradiation. RSC Advances, 2016; 6(34): 28532-28537.

[23] Liu S, Han L, Duan Y, Asahina S, Terasaki O, Cao Y, et al. Synthesis of chiral $\mathrm{TiO}_{2}$ nanofibre with electron transition-based optical activity. Nature communications, 2012; 3: 1215.

[24] Wang X X, Zhao J L, Hou X R, He Q, Tang C C. Catalytic activity of $\mathrm{ZrO}_{2}$ nanotube arrays prepared by anodization method. Journal of Nanomaterials, 2012; 2012:1.

[25] Xie W, Peng H, Chen L. Calcined Mg-Al hydrotalcites as solid base catalysts for methanolysis of soybean oil. Journal of Molecular Catalysis A: Chemical, 2006; 246(1): 24-32.

[26] Bruzzoniti M C, Sarzanini C, Torchia A M, Teodoro M, Testa F, Virga A, et al. MCM-41 functionalized with ethylenediaminetriacetic acid for ion-exchange chromatography. Journal of Materials Chemistry, 2011; 21(2): 369-376.

[27] Chandrasekar G, You K S, Ahn J W, Ahn W S. Synthesis of hexagonal and cubic mesoporous silica using power plant bottom ash. Microporous and Mesoporous Materials. 2008; 111(1): 455-462.

[28] Carvalho D L, de Avillez R R, Rodrigues M T, Borges L E, Appel L G. $\mathrm{Mg}$ and $\mathrm{Al}$ mixed oxides and the synthesis of n-butanol from ethanol. Applied Catalysis A: General, 2012; 415: 96-100.

[29] Iatridis B, Gavalas G R. Pyrolysis of a precipitated kraft lignin. Industrial \& Engineering Chemistry Product Research and Development, 1979; 18(2): 127-130.

[30] Dorrestijn E, Laarhoven L J, Arends I W, Mulder P. The occurrence and reactivity of phenoxyl linkages in lignin and low rank coal. Journal of Analytical and Applied Pyrolysis, 2000; 54(1): 153-192.

[31] Foster A J, Jae J, Cheng Y T, Huber G W, Lobo R F. Optimizing the aromatic yield and distribution from catalytic fast pyrolysis of biomass over ZSM-5. Applied Catalysis A: General, 2012; 423: 154-161.

[32] Idem R O, Katikaneni S P, Bakhshi N N. Catalytic conversion of canola oil to fuels and chemicals: roles of catalyst acidity, basicity and shape selectivity on product distribution. Fuel Processing Technology, 1997; 51(1): 101-125.

[33] Carlson T R, Jae J, Lin Y C, Tompsett G A, Huber G W. Catalytic fast pyrolysis of glucose with HZSM-5: the combined homogeneous and heterogeneous reactions. Journal of Catalysis, 2010; 270(1): 110-124.

[34] Li X, Su L, Wang Y, Yu Y, Wang C, Li X, et al. Catalytic fast pyrolysis of Kraft lignin with HZSM-5 zeolite for producing aromatic hydrocarbons. Frontiers of Environmental Science \& Engineering, 2012; 6(3): 295-303.

[35] Cheng Y T, Wang Z, Gilbert C J, Fan W, Huber G W. Production of $\mathrm{p}$-Xylene from Biomass by Catalytic Fast Pyrolysis Using ZSM-5 Catalysts with Reduced Pore Openings. Angewandte Chemie International Edition, 2012; 51(44): 11097-110100.

[36] Iliopoulou E, Antonakou E, Karakoulia S, Vasalos I, Lappas A, Triantafyllidis K. Catalytic conversion of biomass pyrolysis products by mesoporous materials: effect of steam stability and acidity of Al-MCM-41 catalysts. Chemical Engineering Journal, 2007; 134(1): 51-7.

[37] Kaewpengkrow P, Atong D, Sricharoenchaikul V. Effect of $\mathrm{Pd}, \mathrm{Ru}, \mathrm{Ni}$ and ceramic supports on selective deoxygenation and hydrogenation of fast pyrolysis Jatropha residue vapors. Renewable Energy, 2014; 65: 92-101.

[38] Kaewpengkrow P, Atong D, Sricharoenchaikul V. Catalytic upgrading of pyrolysis vapors from Jatropha wastes using alumina, zirconia and titania based catalysts. Bioresource Technology, 2014; 163: 262-269.

[39] Auta M, Ern L, Hameed B. Fixed-bed catalytic and non-catalytic empty fruit bunch biomass pyrolysis. Journal of Analytical and Applied Pyrolysis, 2014; 107: 67-72.

[40] Wang D, Xiao R, Zhang H, He G. Comparison of catalytic pyrolysis of biomass with $\mathrm{MCM}-41$ and $\mathrm{CaO}$ catalysts by using TGA-FTIR analysis. Journal of Analytical and Applied Pyrolysis, 2010; 89(2): 171-177. 